\title{
PERBANDINGAN KEMAMPUAN PENALARAN MATEMATIS SISWA MELALUI MODEL PEMBELAJARAN KOOPERATIF TIPE THINK TALK WRITE (TTW) DENGAN MODEL PEMBELAJARAN PROBLEM BASED LEARNING (PBL) PADA SISWA KELAS VII SMP NEGERI 5 KOTA JAMBI
}

\author{
Desrani Indah Lia ${ }^{1}$, Relawati ${ }^{2}$, Zulyadaini ${ }^{3}$ \\ Program Studi Pendidikan Matematika, FKIP, Universitas Batanghari ${ }^{1,2,3}$ \\ Jl. Slamet Riyadi No.1 Broni Jambi \\ Email: ranirani688@gmail.com
}

\begin{abstract}
ABSTRAK
Penelitian ini bertujuan adalah untuk mengetahui perbedaan kemampuan penalaran matematis siswa yang melalui model pembelajaran model pembelajaran kooperatif tipe Think Talk Write (TTW) dengan model pembelajaran Problem Based Learning (PBL) pada siswa kelas VII SMP Negeri 5 Kota Jambi. Penelitian ini merupakan penelitian kuantitatif dengan metode quasi eksperimen. Populasi dalam penelitian ini adalah seluruh siswa kelas VII SMP Negeri 5 Kota Jambi Tahun Ajaran 2018/2019. Pengambilan sampel menggunakan simple random sampling dan sampel penelitian yang terambil adalah kelas VII B sebagai kelas eksperimen dan VII E sebagai kelas kontrol. Instrumen yang digunakan dalam penelitian ini adalah tes tertulis kemampuan penalaran matematis. Data dianalisis menggunakan uji t. Hasil penelitian menunjukan bahwa nilai $t_{\text {hitung }}=3,437$ dan $t_{\text {tabel }}=1,67$ pada taraf nyata $\alpha$ sama dengan 0,05 . Dari hasil perhitungan diperoleh $t_{\text {hitung }}>t_{\text {tabel }}$ maka $\mathrm{H}_{1}$ diterima. Berdasarkan hasil akhir dapat disimpulkan bahwa terdapat perbedaan antara rata-rata kemampuan penalaran matematis yang melalui model pembelajaran kooperatif tipe Think Talk Write (TTW)dengan siswa yang melalui model pembelajaran Problem Based Learning (PBL) pada siswa kelas VII SMP Negeri 5 Kota Jambi.
\end{abstract}

Kata kunci:

Penalaran Matematis., Model Pembelajaran Think Talk Write., Model Pembelajaran Problem Based Learning

\begin{abstract}
The purpose of this research is to find out the difference in students' mathematical reasoning abilities through the learning model of the Think Talk Write (TTW) type learning model and the Problem Based Learning (PBL) learning model in Grade VII students of SMP Negeri 5 Jambi City. This research is a quantitative study with a quasi-experimental method. The population in this study were all students of class VII SMP 5 Jambi City Academic Year 2018/2019. Sampling uses simple random sampling and the research sample taken is class VII B as an experimental class and VII E as a control class. The instrument used in this study was a written test of mathematical reasoning ability. Data were analyzed using $t$ test. The results showed that the $t$ count $=3.437$ and $t$-table $=1.67$ at the real level of $\alpha$ equal to 0.05 . From the calculation results obtained t count $>t$ table then $\mathrm{Hl}$ is accepted. Based on the final results it can be concluded that there is a difference between the average mathematical reasoning ability through the cooperative learning model Think Talk Write (TTW) type and students who go through the Problem Based Learning (PBL) learning model in Grade VII students of SMP Negeri 5 Jambi City.
\end{abstract}

Keywords:

Mathematical Reasoning, Think Talk Write Learning Model, Problem Based Learning Learning Model

\section{PENDAHULUAN}

Matematika merupakan ilmu universal yang mendasari perkembangan teknologi modern, mempunyai peran penting dalam berbagai disiplin ilmu pengetahuan dan mengembangkan daya pikir manusia. Matematika merupakan pelajaran di sekolah yang dipandang penting dan dipelajari oleh setiap siswa mulai dari sekolah dasar hingga sekolah 


\section{$\pi$ (Phi)}

lanjutan tingkat atas dan bahkan juga perguruan tinggi ( Fitriani, 2015). Menurut Stacey (Maarif, 2015) mengungkapkan bahwa pemahaman matematika dibangun atas dasar penalaran. Oleh karena itu, kemampuan panalaran matematis harus menjadi bagian penting dalam pembelajaaran matematika pada setiap jenjang pendidikan. Penalaran pada setiap jenjang pendidikan dibangun untuk memperkuat konsep dasar dan melatih proses berpikirnya sehingga siswa terbiasa untuk menggunakan logika dalam setiap pembelajaran matematika.

Berdasarkan hasil observasi penulis di SMP Negeri 5 Kota Jambi, fakta yang diberikan sehubungan masih rendahnya kemampuan penalaran matematis siswa terlihat dari jawaban siswa yang menjawab soal. Siswa kurang memahami maksud dari soal tersebut sehingga tidak dapat memeriksa pernyataan dengan benar dan memberikan penyataan yang benar. Siswa hanya berpikir cara cepat dalam menjawab soal. Kesalahan siswa dalam memeriksa pernyataan dengan benar sekitar $87,60 \%$ atau 318 siswa dari 363 siswa.

Dalam proses pembelajaran yang dilakukan oleh guru di dalam kelas, guru menggunakan model pembelajaran Problem Based Learning (PBL). Model pembelajaran Problem Based Learning (PBL) dalam pelaksanaannya guru lebih berperan aktif dalam pembelajaran dibandingkan siswa, siswa kurang aktif berinteraksi dalam pembelajaran karena siswa malu bertanya dan mengungkapkan pendapatnya kepada guru, semua informasi diberikan oleh guru dan siswa hanya menerima informasi pelajaran yang diberikan oleh guru. Siswa cenderung pasif dalam menerima pelajaran.

Adapun salah satu alternatif untuk memecahkan permasalahan tersebut adalah menggunakan model pembelajaran kooperatif tipe Think Talk Write (TTW). Menurut Sugandi (2011) Think Talk Write adalah model pembelajaran yang berusaha membangun pemikiran, merefleksikan dan mengorganisasi ide, kemudian menguji ide tersebut sebelum siswa diharapkan untuk menuliskan ide-ide tersebut. Model pembelajaran Think Talk Write yang diperkenalkan oleh Huinker dan Laughin, pada dasarnya dibangun melalui berpikir, berbicara dan menulis. Penerapan Think Talk Write memungkinkan seluruh siswa mengeluarkan ide-ide, membangun secara tepat untuk berpikir dan refleksi, mengorganisasi ide-ide, serta mengetes ide tersebut sebelum siswa diminta untuk menulis.

\section{METODE PENELITIAN}

Sesuai dengan permasalahan yang telah dikemukakan sebelumnya, maka penelitian ini merupakan penelitian quasi eksperimen. Desain ini mempunyai kelompok-kelompok kontrol tetapi tidak dapat berfungsi sepenuhnya untuk mengontrol variable-variabel luar yang mempengaruhi pelaksanaan eksperimen (Lestari dan Yudhanegara, 2017). Penelitian ini melibatkan dua kelas yaitu kelas eksperimen dan kelas kontrol dengan perlakuan yang berbeda masing-masing kelas, kelas eksperimen diberi perlukan model pembelajaran kooperatif tipe think talk write sedangkan dikelas kontrol diberi perlakuan model pembelajaran problem based learning.

Populasi dalam penelitian ini adalah seluruh siswa kelas VII SMP Negeri 5 Kota Jambi yang terbagi dalam 10 kelas. Selanjutnya dilakukan pemilihan sampel yang terdiri dari 2 kelas pengambilan sampel pada penelitian ini menggunakan teknik random sampling. Setelah dilakukan analisis diperoleh nilai matematika di skor matematika di semua kelas berdistribusi normal dan memeiliki variasi yang homogeny. Karena uji prasyaratnya sudah terpenuhi maka pengambilan sampel dilakukan dengan acak. Dari hasil pengam bilan secara acak diperoleh kelas VII B 


\section{$\pi$ (Phi)}

sebagai kelas eksperimen dan kelas VII E sebagai kelas kontrol.

Dalam penelitian ini menggunakan desain penelitian berbentuk posttest only control design. Sugiyono (2014) mengemukakan ciri utama rancangan ini adalah sampel yang digunakan untuk eksperimen maupun sebagai kelompok kontrol diambil secara random dari populasi tertentu. Desain penelitian ini tergambar pada table 1 berikut:

Tabel 1. Desain Penelitian

\begin{tabular}{ccc}
\hline Kelompok & Treatment & Post-Test \\
\hline Eksperimen & $\mathrm{X}_{1}$ & $\mathrm{O}_{1}$ \\
Kontrol & $\mathrm{X}_{2}$ & $\mathrm{O}_{2}$ \\
\hline
\end{tabular}

Keterangan :

$\mathrm{X}_{1}=$ Kelas yang mengikuti pembelajaran menggunakan model pembelajaran Think Talk Write (TTW)

$\mathrm{X}_{2}=$ Kelas yang mengikuti pembelajaran menggunakan model pembelajaran Problem Based Learning (PBL).

$\mathrm{O}_{1}=$ Nilai Post test setelah mengikuti pembelajaran dengan model Think Talk Write (TTW)

$\mathrm{O}_{2}=$ Nilai Post test setelah mengikuti pembelajaran dengan model pembelajaran Problem Based Learning (PBL).

\section{HASIL DAN PEMBAHASAN}

Penelitian ini dilaksanakan pada sampel yang terdiri dari dua kelas, yaitu kelas VII B sebagai kelas eksperimen dan kelas VII E sebagai kelas kontrol. Untuk mendapatkan kelas sampel ini dilakukan uji normalitas, uji homogenitas dan uji kesamaan dua rata-rata. Data yang diperoleh siswa pada kelas eksperimen berjumlah 37 orang dan siswa pada kelas kontrol berjumlah 37 orang keduanya diberi perlakuan berbeda, kelas eksperimen melalui model pembelajaran kooperatif tipe Think Talk Write (TTW) sedangkan pada kelas kontrol melalui model pembelajaran Problem Based Learning (PBL).

Untuk uji kesamaan dua rata-rata atau uji hipotesis ini dilakukan dengan uji-t, karena data berdistribusi normal dan memiliki varians yang homogen. Hasil pengujian hipotesis dapat dapat dilihat pada tabel 2 berikut ini :

Tabel 2. Perbedaan Rata-rata Hasil Tes

Kemampuan Penalaran Matematis

\begin{tabular}{cccccc}
\hline Kelas & $\mathbf{N}$ & $\begin{array}{c}\text { Rata- } \\
\text { rata }\end{array}$ & $\mathbf{t}_{\text {hitung }}$ & $\mathbf{d k}$ & $\mathbf{t}_{\text {tabel }}$ \\
\hline Eksperimen & 37 & 32,649 & 3,437 & 72 & 1,67 \\
Kontrol & 37 & 28,135 & & & \\
\hline
\end{tabular}

Berdasarkan keterangan perhitungan pada tabel 2 di atas terlihat bahwa kelas eksperimen berjumlah 37 orang dengan rata-rata 28,43 dan kelas kontrol berjumlah 37 orang dengan rata-rata 24,45 pada $\alpha=$ 0,05 dengan $\mathrm{dk}=72$ maka didapat $\mathrm{t}_{\text {tabel }}=$ $\mathrm{t}_{(\alpha, \mathrm{dk})}=1,67$ karena $\mathrm{t}_{\text {hitung }}>\mathrm{t}_{\text {tabel }}$ yaitu 3,437 $>1,67$ berarti $\mathrm{H}_{0}$ ditolak atau terdapat perbedaan antara rata-rata kemampuan penalaran matematis siswa yang melalui model pembelajaran kooperatif tipe Think Talk Write (TTW) dengan model pembelajaran Problem Based Learning (PBL).

Berdasarkan hasil posttest pada pokok bahasan bilangan, kemampuan penalaran matematis kelas eskperimen yang melalui model pembelajaran kooperatif tipe Think Talk Write (TTW) memperoleh ratarata yang telah di capai sebesar 32,649. Sedangkan kelas kontrol dengan model pembelajaran Problem Based Learning (PBL) memperoleh rata-rata sebesar 28,135.

Keunggulan model pembelajaran kooperatif tipe Think Talk Write (TTW) terletak pada keterlibatan siswa dalam proses pembelajaran. Pembelajaran melalui model pembelajaran kooperatif tipe Think Talk Write (TTW) menekankan perlunya siswa mengkomunikasikan hasil pemikirannya dimulai dari keterlibatan siswa dalam berpikir atau berdialog dengan dirinya sendiri setelah proses membaca, selanjutnya berbicara dan membagi ide 


\section{$\pi$ (Phi)}

(sharing) dengan temannya sebelum menulis.

Pada pelaksanaannya model pembelajaran kooperatif tipe Think Talk Write (TTW) di kelas eksperimen melalui 4 fase pembelajaran diantaranya: fase 1 teams; fase 2 think; fase 3 talk; fase 4 write.

Pada fase 1 yaitu teams. Dalam kegiatan ini peneliti memulai dengan memberikan salam pembuka, menyampaikan tujuan pembelajaran dan pada pertemuan awal guru memberikan penjelasan mengenai model pembelajaran yang akan dijalani. Pada kegiatan ini guru membentuk kelompok sebanyak tujuh kelompok yang terdiri dari lima sampai enam siswa yang dipilih secara heterogen berdasarkan kemampuan siswa yaitu siswa berkemampuan tinggi, sedang dan rendah.

Pada fase 2 think. Dalam tahap ini, siswa membaca teks berupa soal siswa secara individu memikirkan kemungkinan jawaban (strategi penyelesaian), dan membuat catatan kecil tentang ide-ide yang terdapat pada bacaan.

Pada fase 3 talk. Dalam tahap ini, siswa merefleksikan, menyusun, serta menguji (negosiasi, sharing) ide-ide dalam kegiatan diskusi kelompok.

Pada fase 4 write. Dalam tahap ini, siswa menuliskan ide-ide yang diperolehnya dan kegiatan fase pertama dan kedua. Tulisan ini terdiri atas landasan konsep yang digunakan, keterkaitan dengan meteri sebelumnya, strategi penyelesaian dan solusi yang diperolehnya.

\section{SIMPULAN DAN SARAN}

Dari hasil penelitian dan pembahasan yang telah dilakukan dapat disimpulkan rata-rata kemampuan penalaran matematis siswa pada materi bilangan kelas eksperimen yang melalui model pembelajaran kooperatif tipe Think Talk Write (TTW) memperoleh nilai rata-rata 32,649 dengan simpangan baku 3,615 dan kemampuan penalaran matematis siswa pada materi penyajian data kelas kontrol yang melalui model pembelajaran Problem Based Learning (PBL) memperoleh nilai rata-rata 28,135 dengan simpangan baku 3,698.

Kriteria pengujiannya dari uji statistik dengan menggunakan uji t, dimana diperoleh $t_{\text {hitung }}=3,437$ dan $t_{\text {tabel }}=1,67$. Sesuai dengan kriteria pengujian, jika $t_{\text {hitung }}$ $>t_{\text {tabel }}$ maka $\mathrm{H}_{1}$ diterima, sehingga terdapat perbedaan antara rata-rata kemampuan penalaran matematis siswa yang melalui model pembelajaran kooperatif tipe Think Talk Write (TTW) dengan model pembelajaran Problem Based Learning (PBL) siswa kelas VII SMP Negeri 5 Kota Jambi.

\section{DAFTAR PUSTAKA}

Fitriani, S. (2015). Perbandingan Hasil Belajar Matematika Siswa Dengan Menerapkan Strategi Pembelajaran Aktif Tipe Practice-Rehearsal Pairs dan Action Learning di Kelas VIII SMP Negeri 16 Kota Jambi: Ekotrans.15 (1), 91-102.

Lestari, Kurnia Eka dan Yudhanegara, Mokhammad Ridwan. (2017). Penelitian Pendidikan Matematika. Bandung: PT Refika Aditama.

Maarif, Samsul. (2015). Pembelajaran Geometri Berbantu Cabri II Plus. Bogor: In Media.

Sugandi, Asep Ikin. (2011). "Pengaruh Model Pembelajaran Kooperatif Tipe

Think Talk Write Terhadap Kemampuan Komunikasi dan Penalaran Matematis". Jurnal Ilmiah Nasional.

Sugiyono. (2014). Metode Penelitian Pendidikan. Bandung: Alfabeta. 